\title{
Artistic and Communicative Connections between Newspaper Cartooning and Epa Festival in Ijagun Community, Ogun State, Nigeria
}

\author{
Mufutau Oluwakemi Oriola \& Oludare Joseph Tiamiyu \\ https://dx.doi.org/10.4314/jrhr.v13i1.6
}

\begin{abstract}
Newspaper cartoons and Epa masks worn by Epa masquerades are similar in their humorous appearances and communicative values. This study examined the artistic and communicative connections between newspaper cartooning and Epa festival in Ijagun community, Ogun State, Nigeria. Descriptive questionnaire survey was conducted on 20literate indigenous Epa adherents in the community. Findings revealed that Epa festival and newspaper cartooning were related in their significant artistic connection through humour and entertainment, and communication of cultural values through exposure of social vices in the community. The study recommended the preservation of such festivals as Epa for awareness creation, entertainment and security.
\end{abstract}

Keywords: Newspaper Cartooning, Epa Festival, Artistic Connection, Cultural Communication.

\section{Introduction}

The word 'cartoon' is derived from the Italian word 'cartone' meaning paper. The term was used by painters for preliminary drawings on paper which were then transferred, either through tracing or punching, onto surface which may be a ceiling, a large cannas or a wall. The word is commonly used to describe any witty drawing originally published in a periodical that makes its own point, with or without caption (Maslin, 2016).A cartoon is a type 
of illustration, possibly animated, typically in a non-realistic or semirealistic style. The specific meaning has evolved over time, but the modern usage usually refers to either an image or series of images intended for satire, caricature or humor; or a motion picture that relies on a sequence of illustrations for its animation (Keith, 2014).Cartoons are non-realistic or semi-realistic drawings or paintings intended for satire, caricature or humour. They are distorted images in exaggerated and/or emphatic manners and such distortions may evoke feelings such as love, hate, sympathy, hope, kindness, anger, distress and most often, laughter among the reading audience. They are usually contents aimed at entertaining and evoking emotions in a witty manner (Oriola and Quadri, 2019). An artist who creates cartoons is called a cartoonist and the art of creating/producing cartoons for communicative and satirical purposes is called cartooning. Cartoon as a form of visual art is a potent piece of communication through which cartoonists deliver messages in humorous manners to their audiences, who often find such contents pleasurable to read (Tejuoso, 2005).

Keith (2014) explains that the following are the content of any cartoon:

(i) Symbolism: Cartoonists use simple objects, or symbols to represent larger concepts or ideas. After identifying the symbols in a cartoon, the cartoonist considers what each symbol is intended to stand for. Symbolism is important even when people are unsure of how they feel and are unable to decide on the cognitive perspective of their take on issues.

(ii) Exaggeration: Sometimes cartoonists overdo or exaggerate the physical characteristics of people or things in order to make a point. The characteristics a cartoon always seem overblown in their facial characteristics and clothing. Cartoonists use exaggerations in size, emotions, and shape of a person or object for effect. 
(iii) Labeling: Cartoonists often label objects or people to make it clear exactly what they stand for. Cartoonists execute the different labels of the particular person or object which appear in a cartoon.

(iv) Analogy: An analogy is a comparison between two unlike things that share some characteristics. By comparing a complex issue or situation with a more familiar one, cartoonists can help their readers see issues in different lights.

(v) Irony: Irony is the difference between the ways things are and the way things should be, or the way things are expected to be. Cartoonists often use irony to express their opinion on an issue. When one looks at a cartoon, one can possibly find an irony in the situation the cartoon depicts.

(vi) Stereotypes and Caricature: Stereotyping is common in cartoons. It's in a stereotype that the cartoonist tries and explains and simplifies a largely applicable point of view. It promotes a point of view, for example, all cricket matches are fixed. Although sometimes offensive, cartoons make a strong point which can be debated upon, thereby opening grounds for discussions.

Newspaper cartoons are humorous drawings or series of drawings that tell stories about human actions or inaction in the society. Agberia (2003) considers newspaper cartoons as an important medium for the formation of public opinions on salient social issues. They are seen as "both, opinion-mounding and opinion-reflecting" tools, and they provide subtle frameworks within which to examine the life and political process of a nation (Caswell, 2002: 14). Newspaper cartoons are intended to transform otherwise complex and opaque social events and situations into quick and easily readable depictions that facilitate comprehension of the nature of social issues and events. In doing so, they present the society with visually palpable and hyper-ritualized depictions (selectively exaggerated portions of reality) that attempt to reveal the essence and meaning of social events (Agberia, 2003). 
Cartooning has become an integral part of newspaper publication in modern times. Newspaper cartoons throughout Nigerian modern history reveal that they have served as unique windows useful in understanding local and national politics. Using imagery, metaphor, symbolism and others rhetorical devices, the cartoonist defines political situations and attempts to interpret them visually in a way that is both amusing and thought-provoking. The exploits of Akinola Lasekan with his editorial cartoons in the West African Pilot in the 1940 and 1950s reflected colonial life, and also depicted the struggle for nationhood which later culminated in Nigeria's independence in 1960 (Olaniyan, 2002).

Some of the roles of cartooning in newspaper according to Nasiru and Buike (2017) are:

i. Cartoons serve as a form of entertainment to newspaper readers.

ii. Cartoons provide comic relief to readers who are stressed up.

iii. Cartoons inform readers of the social ills going on within their environment.

iv. Cartoons complement the editorial for easier and better understanding, especially for impatient readers who donot like reading lengthy write-ups.

v. Cartoonists use cartoons to express what cannot otherwise be expressed in news/features/editorials.

vi. Cartoons provide readers with the platform of the formation of public opinion.

vii. Newspapers use cartoons to attack or criticize corrupt public office holders in un-harmful manners.

Cartoons have various impacts on society and people. It is a form of entertainment, an important part of newspaper publications, a medium of social awareness and criticism and a creative tool in advertising and other forms of promotion. According to Johnston and Graham, (2012), cartooning has been one of the most significant tools in propagating and promoting the cultural heritage in Nigeria. 
Epa mask is a ceremonial mask worn by Epa masquerades among the Yoruba people of Nigeria during Epa festivals. Carvings representing priests, hunters, farmers, kings, and mothers are usually depicted on the masks. They are used to acknowledge certain important roles within the community and to honor those who perform such roles, both ancestral and present (Birmingham Museum of Art, 2010) Epa masks often consist of elaborate figurative superstructure carved with soft wood which are usually regarded as "headpiece or headdress." Headpieces are named according to the motif carved on it. Important social events, such as initiation rites, or coming-of-age ceremonies, often include these masquerades. Spirits acting through masked performers oversee the symbolic rebirth of adolescents into adults. They also may appear in the public ceremonies that present the new adults to the community. Masks also play important roles in Epa festival celebrations (Abokede, 2018).

Epa masks originated in the 17 kingdoms which make up the present Ekiti State in the North-eastern part of Yorubaland in Nigeria. Unlike other parts of Yorubaland, Ekiti has been exposed to extensive foreign influences. The area received successive waves of immigration from Ife in the 16th century and from the Bini in the 17 th, as well as being the target of military raids from Ilorin and Ibadan in the middle or late 19th century (Forde, 1951). Until the beginning of the nineteenth century the area was considered to have formed part of the Benin Empire (Akintoye, 1961). Consequently, its population has a complex mixed ethnic origin which has given rise to some unique traditions not previously found elsewhere in Yorubaland but which have since spread to the Iyagba, Igbomina, Oshun, Owo and Ijesha regions. It is also not surprising to find that the warrior figures often surmounting Epa masks represent heroes who proved their mettle during this long period of instability (Shelton, 1998).

Oral historical tradition traces the origin of Ijagun community in the present-day Odogbolu Local Government Area of Ogun State to 
Oriola \& Tiamiyu: Artistic and Communicative Connections between Newspaper Cartooning and Epa Festival in Ijagun Community, Ogun State, Nigeria

Ado Ekiti, the present-day capital of Ekiti State, Nigeria. Jatoro, the founder of Ijagun was a great man, brave hunter and herbalist who migrated with his brother Akofa from Owodaiye where Ajebu also migrated from. When he was coming, he had a short stop-over at Ado in Ekiti State. This affinity of Ijegun community with Ado Ekiti can be seen in the Oriki of Ijagunthus: Omoljagun Ado, Omo Ado regiregi. Jatoro. After some years of dwelling at Ado, the oracle which served as the Atona (map) was consulted and they were advised to proceed further on their journey. So they moved out of Ado Ekiti to Porogun area of Ijebu Ode in Ijebu Ode Local Government of Ogun State where he practiced as a great hunter and herbalist. He assisted Oba Fesojoye, the 36th Awujale of Ijebu-land in resolving the problem of the death of male children in his palace who rewarded him with a chieftaincy title called Oloja with a staff of office, a sword of power and political autonomy in his own settlement at Agemoji where he has been farming and hunting. Against the strong opposition of the chiefs and one of his wives, Oba Fesojoye gave Jatoro the Agemojiland and asked him to go and settle there with hispeople. Jatoro named his new settlement Jagun-la, which means "a great battle fought and won" from which the present name of the community - Ijagun - was derived. After settling at Jagun-la, Jatoro and his descendants continued the Epa festival which they inherited from their origin in Ado Ekiti.

Epa festival was originally celebrated annually between the months of April and June. However, in Ijagun community, the celebration now comes up between December and January, around the Christmas and New Year period when most of the youthful adherents are back in the community for the celebrations. The festival features various types of masquerades characterized by highly adorned costumes and props such as masks, gongs, bells, palm fronds, and several others that constitute Epa masquerade. Scholars such as Abokede (2009) and Ayinmode (2005) have studied Epa masquerades 
in respect to its origin, classification, costume, masks, paintings, spiritual identities and functions and classified them into types based on their native creation and communities of origin.

In North-West Yorubaland, the Epa masks are kept by the head of each lineage or community head on behalf of the lineage or community. When in use, they are choreographed as emerging from the bush where they return once the festival is completed. Offerings may be made to a mask before it is used or during the ceremony. According to Thompson (1974), the Epa cult stresses the transformation of young men into stalwart specimens able to bear pain and shoulder heavy weight. King Arowolo of lloro Ekiti in Ekiti State, Nigeria distinguished between the type of energy belonging to the cult of Elefon, concerned with ancestral spirits, and the cult of Epa, connected with the dignified, slow and patient masquerades of ancient men and culture heroes (Heyden, 1977).

In North-eastern Yorubaland, Epa and other masks are used in annual ceremonies, held in February or March in some places or as late as September in others to promote fertility and well-being of the community (Ojo, 1978). They also appear in Elefon festivals performed to celebrate the return of the warriors, to honor Ogun, the god of war and iron and to mark the growth of new crops. Elsewhere, such masks were used in post-burial rites of titled men. In one fairly consistent episode in the festival, the masquerader, supporting a mask which can often weigh $50 \mathrm{~kg}$ or more, attempts to jump off a mound to augur the quality of the New Year. A fall or loss of balance is read as bad omen which may herald coming misfortune (Shelton, 1998).

Epa ceremonies are entirely focused on fertility. However, others have found the ceremonies to be equally concerned with warriors and the medicine "god" (Osanyin), relating them to both physical and spiritual security. Ojo (1978) corroborating Carroll (1967) observed that at one level, the ceremonies incorporate the re-enactment of historical events. In IloroEkiti, Ekiti State, Nigeria, masks surmounted 
Oriola \& Tiamiyu: Artistic and Communicative Connections between Newspaper Cartooning and Epa Festival in Ijagun Community, Ogun State, Nigeria

by female figures were identified as the wives of the warrior Okotorojo, represented by an animal mask resembling a goat or antelope. Okotorojo, the principal figure in the festival, was chained to another man described as either having the duty to restrain the wild powers of the warrior or, paradoxically, as the representative of the power (ase) of the creator (Eleda), who always remains behind the warrior to render him invincible in battle.

Epa masks are used to promote health and wellbeing within a community by celebrating and honouring ancestors, cultural heroes and important individuals (including mothers, priests, farmers, kings and hunters) within a village. Originating in Ekiti and spreading to much of North-Eastern Yoruba towns (including Owo, Efon Alaye, Igbomina and Ijesa), the bi-annual, week-long Epa festival acknowledges the roles these individuals have played in building a successful community.

The Olomoyeye's (also called eyelashe, iyaolomo, olomoyoyo, omoniyi, olomopupo or omobomi, meaning owner of many children) mask depicts a mother with many children representing the important role women play in baring children and extending the lineage of men in the community. Common features among all Epa masks include according to Ayinmode and Abokede (2016) are made of wood from the Iroko tree, whole mask carved from single piece of wood, weighing between 23 and $50 \mathrm{~kg}$, up to 1.5 meters height, painted in red and blue, Janus faced Iroko helmet (believed to be the container of spiritual power 'ase'). The helmet typically has two faces on both sides: one set of eyes open (looking at world of living) and other set closed (looking into the realm of ancestors). Also, there are bulging almond shaped eyes on helmet; rectangular mouth; elaborate figurative superstructure separated from mask by thick disk; superstructure carvings in centre representing priests, hunters, farmers, kings, and mothers. Meanwhile, smaller figures can surround the central figure (representing traders, musicians, hunters); sub-type 
variations (Olomoyeye - Mother of Many Children): superstructure depicting a mother surrounded by many children, one central female figure (sitting or standing) with one or more children surrounding her and can be depicted carrying a child on her back or on her knee. However, the central female figure is carved with domed headdress or elaborate plaited hairstyle (representing high rank in the community) and sometimes carved holding a fan in the right hand or with shawl draped over the left arm or shoulder (also signs of high rank) (See figure 1).

Epa masqueraders perform slow, steady and controlled movements due to the huge and heavy masks they carry on their heads during performances. The masqueraders dance around the community and must jump on a raised mound to demonstrate their ability to maintain balance. It is believed to be a bad omen for the town (sometimes leading to misfortune) if the mask should fall off the performer's head during the jump. When not in use, the masks are kept in shrines where villagers can pray to and provide offerings to ancestors. Epa masquerades express artistic projection of a people's image reality as perceived and conceived through masking performance, forms and visual contents. Their headdresses or masks aesthetically reflect varying themes and display colourful complements to traditional costumes, thereby facilitating and strengthening Epa tradition. Just like cartoons, Epa masks worn by Epa masquerades have humorous and communicative values. They both pass across socio-cultural messages in a witty form. 
Oriola \& Tiamiyu: Artistic and Communicative Connections between Newspaper Cartooning and Epa Festival in Ijagun Community, Ogun State, Nigeria

Figure 1: Epa Masks worn by Epa Masquerades

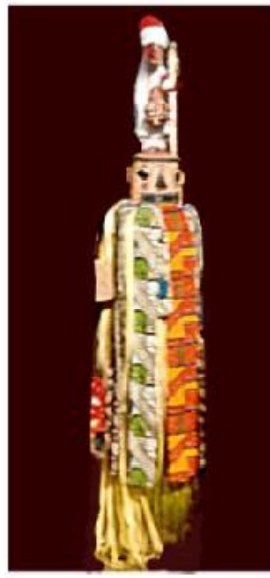

Plate 1: Aro

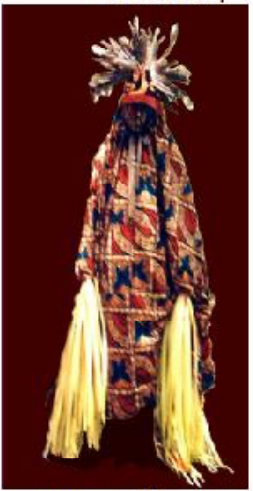

Plate 5: Akorowo

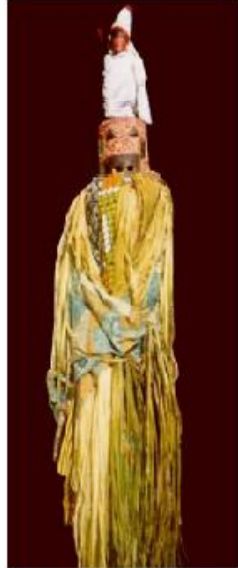

Plate 2:Ote

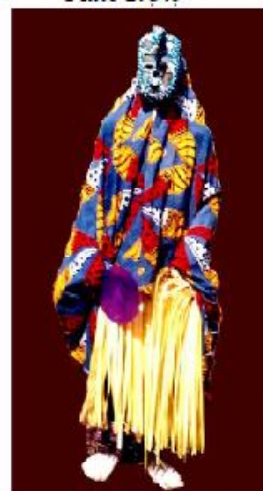

Plate 6: Eye.

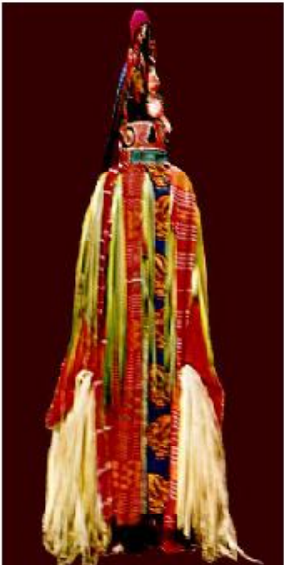

Plate 3: Ologun.

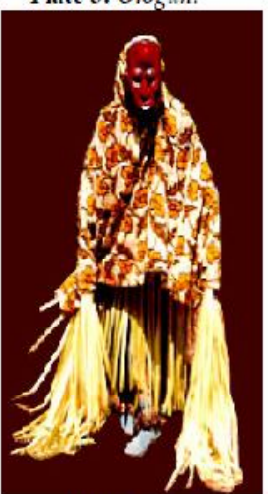

Plate 7: Mistress

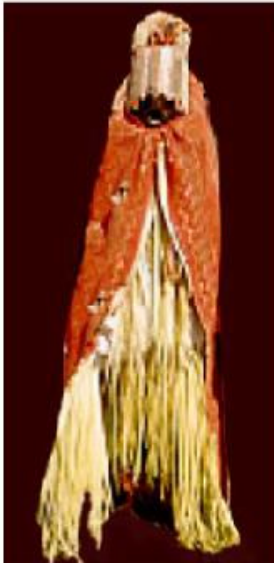

Plate 4: Esu-Obaba Source: Abokede (2018)

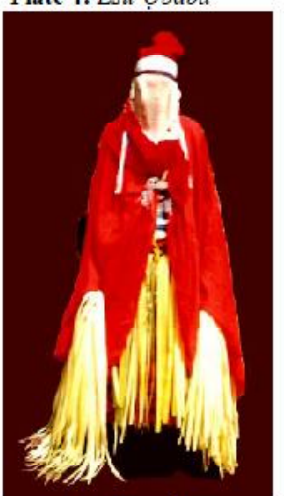

Plate 8: $A g b a$

Various researchers have dwelt on the role of newspaper cartooning on politics and democracy but no adequate research attention, if any, has been place on its artistic and communicative connections newspaper cartooning and cultural festivals such as Epa. 
Against this gap that this study was focused to examine the artistic and communicative connections between newspaper cartooning and Epa festival celebration, particularly among people of Ijagun community in Odogbolu Local Government Area of Ogun State, Nigeria. Specifically, this study aimed to ascertain the communicative values of newspaper cartoons, determine the aesthetic values of Epa festival, evaluate the artistic connection between newspaper cartons and Epa mask and examine the communicative connection between newspaper cartooning and Epa festival among the people of Ijagun community in Odogbolu Local Government Area of Ogun State, Nigeria.

\section{Methodology}

Descriptive survey was the research design adopted in this study. The population of this study comprised male and female adult indigenous residents of Ijagun community, who were adherents of Epa masquerades by virtue of their regular participation in the annual Epa festival in Ijagun community, Odogbolu Local Government Area of Ogun State. Purposively sampling technique was applied to select a sample of twenty (20) literate Epa adherents who were indigenous residents of Ijagun community in this study. This study used structure questionnaire and personal observation during the 2020 Epa festival as research instruments in order to validate empirical data generated through the questionnaire with real life observation. Materials used included tape recorder and camera. 
Oriola \& Tiamiyu: Artistic and Communicative Connections between Newspaper Cartooning and Epa Festival in Ijagun Community, Ogun State, Nigeria

\section{Findings}

Table 1:Respondents' Demographic Information

\begin{tabular}{|lll|}
\hline Option & Frequency & Percentage \\
\hline Sex & 18 & \\
Male & 2 & $90 \%$ \\
Female & & $10 \%$ \\
Education Background & 5 & $25 \%$ \\
Primary & 8 & $40 \%$ \\
Secondary & 7 & $35 \%$ \\
Tertiary Institution & & \\
Age & 4 & $20 \%$ \\
$20-30$ years & 8 & $40 \%$ \\
$31-40$ years & 5 & $25 \%$ \\
41 - 50 years & 3 & $15 \%$ \\
51 years and above & $\mathbf{2 0}$ & $\mathbf{1 0 0 \%}$ \\
\hline Total & & \\
\hline
\end{tabular}

Source: Field Survey (2020)

Table 1 above shows the demographic data of the study respondents. Based on gender, 18 of the respondents representing $90 \%$ were male, while 2 respondents representing $10 \%$ were female. On the educational qualification of the respondents, 5 respondents representing $25 \%$ were primary school certificate holders, 8 respondents representing $40 \%$ were secondary school holder, while 7 respondents representing 35\% were graduates of higher institutions. Thus, majority of the respondents $(75 \%)$ were literate enough to complete the study questionnaire by themselves while the remaining were staunch adherents who completed the questionnaire under the researcher's supervision. In terms of the age, 4 respondents representing 20\% were between 20 years and 30 years of age, 8 respondents representing $40 \%$ were between 31 years and 40 years, while 5 respondent representing $25 \%$ were between 41 years and 50 
years and 3 respondents representing $15 \%$ were 51 years and above respectively. The involvement of youths of between 20 years and 40 years in the Epa festival suggests the passing down of the cultural heritage from the older to the younger generation. The gender and age distributions among adherents in Ijagun community were confirmed by the researcher's observation of active participation of more male and youths respectively in the 2020 celebration.

\section{Artistic and Communicative Functions of Newspaper Cartoons Table 2: Respondents' Perception of Artisticand Communicative Roles of Newspaper Cartoons}

\begin{tabular}{|c|c|c|c|c|c|c|c|c|}
\hline $\mathbf{S} / \mathbf{N}$ & Item & $\begin{array}{c}4 \\
\text { SA }\end{array}$ & $\begin{array}{l}\mathbf{3} \\
\mathbf{A}\end{array}$ & $\begin{array}{l}\mathbf{2} \\
\mathbf{D}\end{array}$ & $\begin{array}{c}1 \\
\text { SD }\end{array}$ & Total & $\begin{array}{c}\text { Av. } \\
\text { Mean }\end{array}$ & Remark \\
\hline 1 & $\begin{array}{l}\text { Cartoon serves as a } \\
\text { form of entertainment } \\
\text { to newspaper readers } \\
\text { through humour. }\end{array}$ & $\begin{array}{c}10 \\
50 \%\end{array}$ & $\begin{array}{c}8 \\
40 \%\end{array}$ & $\begin{array}{c}1 \\
5 \%\end{array}$ & $\begin{array}{c}1 \\
5 \%\end{array}$ & 20 & 3.35 & Agreed \\
\hline 2 & $\begin{array}{l}\text { Newspaper cartoons } \\
\text { provide comic relief } \\
\text { to readers who are } \\
\text { stressed up. }\end{array}$ & $\begin{array}{c}12 \\
60 \%\end{array}$ & $\begin{array}{c}6 \\
30 \%\end{array}$ & $\begin{array}{c}1 \\
5 \%\end{array}$ & $\begin{array}{c}1 \\
5 \%\end{array}$ & 20 & 3.45 & Agreed \\
\hline 3 & $\begin{array}{l}\text { Newspaper cartoons } \\
\text { inform readers of the } \\
\text { social ills going on } \\
\text { within their } \\
\text { environment using } \\
\text { satire. }\end{array}$ & $\begin{array}{c}13 \\
65 \%\end{array}$ & $\begin{array}{c}5 \\
25 \%\end{array}$ & $\begin{array}{c}2 \\
10 \%\end{array}$ & - & 20 & 3.55 & $\begin{array}{c}\text { Strongly } \\
\text { Agreed }\end{array}$ \\
\hline 4 & $\begin{array}{l}\text { Newspaper cartoon } \\
\text { provide readers with } \\
\text { the platform of } \\
\text { formation of public } \\
\text { opinion }\end{array}$ & $\begin{array}{c}15 \\
75 \%\end{array}$ & $\begin{array}{c}3 \\
15 \%\end{array}$ & $\begin{array}{c}1 \\
5 \%\end{array}$ & $\begin{array}{c}1 \\
10 \%\end{array}$ & 20 & 3.6 & $\begin{array}{c}\text { Strongly } \\
\text { Agreed }\end{array}$ \\
\hline
\end{tabular}


Oriola \& Tiamiyu: Artistic and Communicative Connections between Newspaper Cartooning and Epa Festival in Ijagun Community, Ogun State, Nigeria

\begin{tabular}{|c|c|c|c|c|c|c|c|c|}
\hline 5 & $\begin{array}{l}\text { Newspapers use } \\
\text { cartoons to criticize } \\
\text { corrupt public office } \\
\text { holders in an un- } \\
\text { harmful manner }\end{array}$ & $\begin{array}{c}10 \\
50 \%\end{array}$ & $\begin{array}{c}5 \\
25 \%\end{array}$ & $\begin{array}{c}3 \\
15 \%\end{array}$ & $\begin{array}{c}2 \\
10 \%\end{array}$ & 20 & 3.15 & Agreed \\
\hline \multicolumn{2}{|c|}{ Total } & $\begin{array}{c}60 \\
60 \%\end{array}$ & $\begin{array}{c}27 \\
27 \%\end{array}$ & $\begin{array}{c}\mathbf{8} \\
\mathbf{8 \%}\end{array}$ & $\begin{array}{c}5 \\
5 \%\end{array}$ & $\begin{array}{c}100 \\
100 \%\end{array}$ & 3.42 & Agreed \\
\hline
\end{tabular}

Source: Field Survey (2020)

Table 2 shows the respondents' perception of artistic and communicative roles of cartooning in Newspaper. The average mean score of 3.42 shows that the respondents agreed that cartoon played significant artistic and communicative functions in newspapers. Specifically, respondents agreed that cartoons served as a form of entertainment to newspaper readers through humour (Av. mean $=$ $3.35)$, and provided comic relief to readers (Av. mean $=3.45)$. They strongly agreed that cartoons informed readers of the social ills going on within their environment using satire (Av. mean $=3.55)$, and that cartoons provided readers with the platform of formation of public opinion (Av. mean = 3.6). Results also show that the respondents strongly agreed that newspapers used cartoons to attack or criticize corrupt public office holders in an un-harmful manner $(\mathrm{Av}$. mean $=$ 3.15).From the above result, it can be inferred that newspaper cartooning play significant artistic role of entertainment, comic relief and satire, and communicative functions of exposing ills, serving as opinion molding tools and criticizing public official in un-harmful manners. The result that cartoons, in spite of their witty nature, play strong agenda setting roles in newspapers has been asserted in Oriola (2012) and that the satirical drawings carry concrete messages that are topical and are reflective of the current issues in the society as reaffirmed in Oriola and Quadri (2019). 
Newspaper Cartooning and the Promotion of Culture

Table 3: Effectiveness of newspaper cartooning in the promotion of culture

\begin{tabular}{|c|c|c|c|c|c|c|c|c|}
\hline $\mathbf{S} / \mathbf{N}$ & Item & $\begin{array}{c}4 \\
\text { SA }\end{array}$ & $\begin{array}{l}\mathbf{3} \\
\mathbf{A}\end{array}$ & $\begin{array}{l}\mathbf{2} \\
\text { D }\end{array}$ & $\begin{array}{c}1 \\
\text { SD }\end{array}$ & Total & $\begin{array}{c}\text { Av. } \\
\text { Mean }\end{array}$ & Remark \\
\hline 1 & $\begin{array}{l}\text { Newspaper } \\
\text { cartooning give } \\
\text { people a sense of } \\
\text { familiarity with their } \\
\text { culture }\end{array}$ & $\begin{array}{c}11 \\
55 \%\end{array}$ & $\begin{array}{c}6 \\
30 \%\end{array}$ & $\begin{array}{c}2 \\
10 \%\end{array}$ & $\begin{array}{c}1 \\
5 \%\end{array}$ & 20 & 3.35 & Agreed \\
\hline 2 & $\begin{array}{lr}\text { Cartoons } & \text { reinforce } \\
\text { opinions } & \text { about } \\
\text { acceptable norms and } \\
\text { values in the society. }\end{array}$ & $\begin{array}{c}14 \\
70 \%\end{array}$ & $\begin{array}{c}4 \\
20 \%\end{array}$ & $\begin{array}{c}1 \\
5 \%\end{array}$ & $\begin{array}{c}1 \\
5 \%\end{array}$ & 20 & 3.55 & $\begin{array}{c}\text { Strongly } \\
\text { Agreed }\end{array}$ \\
\hline 3 & $\begin{array}{lr}\text { Newspaper } & \\
\text { cartooning } & \text { presents } \\
\text { to the audience } \\
\text { different } \\
\text { situations } \\
\text { humour. }\end{array}$ & $\begin{array}{c}10 \\
50 \%\end{array}$ & $\begin{array}{c}6 \\
30 \%\end{array}$ & $\begin{array}{c}3 \\
15 \%\end{array}$ & $\begin{array}{c}1 \\
5 \%\end{array}$ & 20 & 3.25 & Agreed \\
\hline 4 & $\begin{array}{l}\text { Cartoons are always } \\
\text { unbiased despite their } \\
\text { exaggeration. }\end{array}$ & $\begin{array}{c}16 \\
80 \%\end{array}$ & $\begin{array}{c}4 \\
20 \%\end{array}$ & - & - & 20 & 3.8 & $\begin{array}{c}\text { Strongly } \\
\text { Agreed }\end{array}$ \\
\hline 5 & $\begin{array}{l}\text { Cartoonists use } \\
\text { cartoons to express } \\
\text { cultural issues that } \\
\text { cannot otherwise be } \\
\text { expressed in } \\
\text { news/features/editori } \\
\text { als. }\end{array}$ & $\begin{array}{c}11 \\
55 \%\end{array}$ & $\begin{array}{c}6 \\
30 \%\end{array}$ & $\begin{array}{c}2 \\
10 \%\end{array}$ & $\begin{array}{c}1 \\
5 \%\end{array}$ & 20 & 3.35 & Agreed \\
\hline \multicolumn{2}{|c|}{ Total } & $\begin{array}{c}62 \\
62 \%\end{array}$ & $\begin{array}{c}26 \\
26 \%\end{array}$ & $\begin{array}{c}8 \\
8 \%\end{array}$ & $\begin{array}{c}4 \\
4 \%\end{array}$ & $\begin{array}{c}100 \\
100 \%\end{array}$ & 3.46 & Agreed \\
\hline
\end{tabular}

Source: Field Survey (2020)

Table 3 shows the effectiveness of newspaper cartooning in the promotion of culture as perceived by the study respondents. The average mean score of 3.46 shows that respondents agreed that 
Oriola \& Tiamiyu: Artistic and Communicative Connections between Newspaper Cartooning and Epa Festival in Ijagun Community, Ogun State, Nigeria

cartoons are effective in promoting culture in the society. specifically, findings show that the respondents agreed that newspaper cartoons gave people a sense of familiarity with their culture (Av. mean $=$ 3.35), presented different societal situations to the audience with humour (Av. mean $=3.25$ ) and that cartoonists used cartoons to express cultural issues that cannot otherwise be expressed in news, features or editorials (Av. mean = 3.35).However, the respondents strongly agreed that cartoons reinforce opinions about acceptable norms and values in the society (Av. mean $=3.25$ ) and that cartoons are always unbiased despite their exaggeration (Av. mean $=3.8$ ).From the foregoing, it can be deduced that cartooning is effective in the promotion of culture, as perceived among people of Ijagun community in Ogun State, Nigeria. Thus, it can be said that cartoons are instrumental to the performance of cultural transmission roles in newspapers - a function that ascribes the roles of cultural teachers to the media (McQuail, 2010).

\section{Cultural Values of Epa Festival}

Table 4: Cultural values of Epa festival celebration among people of Ijagun, Ogun State

\begin{tabular}{|c|c|c|c|c|c|c|c|c|}
\hline $\mathbf{S} / \mathbf{N}$ & Item & $\begin{array}{c}4 \\
\text { SA }\end{array}$ & $\begin{array}{r}\mathbf{3} \\
\mathbf{A}\end{array}$ & $\begin{array}{l}\mathbf{2} \\
\mathbf{D}\end{array}$ & $\begin{array}{c}1 \\
\text { SD }\end{array}$ & Total & $\begin{array}{c}\text { Av. } \\
\text { Mean }\end{array}$ & Remark \\
\hline 1 & $\begin{array}{l}\text { Epa masquerade } \\
\text { promotes the fertility } \\
\text { and well-being of the } \\
\text { community. }\end{array}$ & $\begin{array}{c}12 \\
60 \%\end{array}$ & $\begin{array}{c}5 \\
25 \%\end{array}$ & $\begin{array}{c}2 \\
10 \%\end{array}$ & $\begin{array}{c}1 \\
5 \%\end{array}$ & 20 & 3.4 & Agreed \\
\hline 2 & $\begin{array}{l}\text { Epa festival } \\
\text { incorporates the re- } \\
\text { enactment of } \\
\text { historical events. }\end{array}$ & $\begin{array}{c}9 \\
45 \%\end{array}$ & $\begin{array}{c}8 \\
40 \%\end{array}$ & 1 & $\begin{array}{c}2 \\
10 \%\end{array}$ & 20 & 3.2 & Agreed \\
\hline 3 & $\begin{array}{l}\text { Celebrating and } \\
\text { honouring } \\
\text { ancestorsare the core } \\
\text { values of } E p a \\
\text { festival. }\end{array}$ & $\begin{array}{c}15 \\
75 \%\end{array}$ & $\begin{array}{c}4 \\
20 \%\end{array}$ & - & $\begin{array}{c}1 \\
5 \%\end{array}$ & 20 & 3.65 & $\begin{array}{c}\text { Strongly } \\
\text { Agreed }\end{array}$ \\
\hline
\end{tabular}




\begin{tabular}{|c|c|c|c|c|c|c|c|c|}
\hline 4 & $\begin{array}{l}\text { Epa festival plays } \\
\text { important roles in } \\
\text { customs such as } \\
\text { initiation rites and } \\
\text { funeral. }\end{array}$ & $\begin{array}{c}13 \\
65 \%\end{array}$ & $\begin{array}{c}5 \\
25 \%\end{array}$ & $\begin{array}{c}2 \\
10 \%\end{array}$ & - & 20 & 3.55 & $\begin{array}{c}\text { Strongly } \\
\text { Agreed }\end{array}$ \\
\hline 5 & $\begin{array}{l}\text { Epa festival } \\
\text { represents spiritual } \\
\text { manifestations of } \\
\text { dramatic } \\
\text { entertainments and } \\
\text { religiosity. }\end{array}$ & $\begin{array}{c}12 \\
60 \%\end{array}$ & $\begin{array}{c}7 \\
35 \%\end{array}$ & $\begin{array}{c}1 \\
5 \%\end{array}$ & - & 20 & 3.55 & $\begin{array}{c}\text { Strongly } \\
\text { Agreed }\end{array}$ \\
\hline \multicolumn{2}{|c|}{ Total } & $\begin{array}{c}61 \\
61 \%\end{array}$ & $\begin{array}{c}29 \\
29 \%\end{array}$ & $\begin{array}{c}6 \\
6 \%\end{array}$ & $\begin{array}{c}4 \\
4 \%\end{array}$ & $\begin{array}{c}100 \\
100 \%\end{array}$ & 3.47 & Agreed \\
\hline
\end{tabular}

Source: Field Survey (2020)

Results in Table 4 show that generally, respondents agreed that Epa festival was of cultural values to the people of Ijagun community (Av. mean $=3.47)$. Specifically, respondents agreed that Epa masquerade promoted fertility and well-being of the community (Av. mean $=3.4$ ) and that Epa festival incorporated the re-enactment of historical events $($ Av. mean $=3.2)$. They strongly agreed that celebrating and honouring ancestors were the core values of Epa festival (Av. mean = 3.65), that Epa festival played important roles in customs such as initiation rites and funeral (Av. mean $=3.55)$ and that Epa festival represented spiritual manifestations of dramatic entertainments and religiosity. From the foregoing, respondents agreed to the cultural and spiritual values of Epa festival, the reason for its sustenance. Personal observation by the researcher revealed that sustaining the festival was of paramount communal interest. In order to avoid its extinction, older adherents of Epa masquerades who are no longer agile enough to bear its heavy costume are transferring the heritage to younger ones. This accounts for the active involvement of youth adherents in the traditional festival. In order to encourage their sustained involvement, the annual celebration which originally took place 
Oriola \& Tiamiyu: Artistic and Communicative Connections between Newspaper Cartooning and Epa Festival in Ijagun Community, Ogun State, Nigeria

between April and June has been shifted to the period of the Christmas and New Year holidays when youths who have travelled far and near usually return home to observe the traditional festival alongside the Christmas and New Year celebrations.

\section{Artistic and Communicative Connections between Newspaper cartooning and Epa Festival}

Table 5: Artistic and communicative connections between newspaper cartoons and Epa Festival among the people of Ijagun community

\begin{tabular}{|c|c|c|c|c|c|c|c|c|}
\hline $\mathbf{S} / \mathbf{N}$ & Item & $\begin{array}{c}4 \\
\text { SA }\end{array}$ & $\begin{array}{r}\mathbf{3} \\
\mathbf{A}\end{array}$ & $\begin{array}{l}2 \\
\text { D }\end{array}$ & $\begin{array}{c}1 \\
\text { SD }\end{array}$ & Total & $\begin{array}{c}\text { Av. } \\
\text { Mean }\end{array}$ & Remark \\
\hline 1 & $\begin{array}{l}\text { Epa masquerade } \\
\text { serves the purpose of } \\
\text { awareness creation } \\
\text { about societal } \\
\text { happenings like } \\
\text { newspaper cartoons }\end{array}$ & $\begin{array}{c}16 \\
80 \%\end{array}$ & $\begin{array}{c}3 \\
15 \%\end{array}$ & $\begin{array}{c}1 \\
5 \%\end{array}$ & - & 20 & 3.75 & $\begin{array}{l}\text { Strongly } \\
\text { Agreed }\end{array}$ \\
\hline 2 & $\begin{array}{l}\text { Newspaper cartons } \\
\text { and Epa have } \\
\text { humorous } \\
\text { appearances that } \\
\text { entertain people in } \\
\text { the community. }\end{array}$ & $\begin{array}{c}13 \\
65 \%\end{array}$ & $\begin{array}{c}4 \\
20 \%\end{array}$ & 2 & $\begin{array}{c}1 \\
5 \%\end{array}$ & 20 & 3.45 & Agreed \\
\hline 3 & $\begin{array}{l}\text { Entertaining songs } \\
\text { during Epa festival } \\
\text { expose wrongdoings } \\
\text { in the community like } \\
\text { newspaper cartoons. }\end{array}$ & $\begin{array}{c}11 \\
55 \%\end{array}$ & $\begin{array}{c}5 \\
20 \%\end{array}$ & 2 & $\begin{array}{c}2 \\
10 \%\end{array}$ & 20 & 3.25 & Agreed \\
\hline 4 & $\begin{array}{l}\text { Entertaining dance } \\
\text { during Epa festival } \\
\text { helps to understand } \\
\text { the mood of the } \\
\text { country at any time. }\end{array}$ & $\begin{array}{c}10 \\
50 \%\end{array}$ & $\begin{array}{c}8 \\
40 \%\end{array}$ & 1 & $\begin{array}{c}1 \\
5 \%\end{array}$ & 20 & 3.35 & Agreed \\
\hline
\end{tabular}




\begin{tabular}{|c|c|c|c|c|c|c|c|c|}
\hline 5 & $\begin{array}{l}\text { Epa masks illustrate } \\
\text { images and give the } \\
\text { impression of } \\
\text { movement like } \\
\text { animated images in } \\
\text { newspaper cartoons. }\end{array}$ & $\begin{array}{c}12 \\
60 \%\end{array}$ & $\begin{array}{c}6 \\
30 \%\end{array}$ & 0 & $\begin{array}{c}2 \\
10 \%\end{array}$ & 20 & 3.4 & Agreed \\
\hline \multicolumn{2}{|c|}{ Total } & $\begin{array}{c}62 \\
62 \%\end{array}$ & $\begin{array}{c}26 \\
26 \%\end{array}$ & $\begin{array}{c}6 \\
6 \%\end{array}$ & $\begin{array}{c}6 \\
6 \%\end{array}$ & $\begin{array}{c}100 \\
100 \%\end{array}$ & 3.44 & Agreed \\
\hline
\end{tabular}

Source: Field Survey (2020)

Table 5 shows that generally, respondents agreed that there were the artistic and communicative connections between newspaper cartons and Epa mask among people of Ijagun (Av. mean =3.44). In specific terms, respondents strongly agreed that Epa masquerade serves the purpose of awareness creation about societal happenings like newspaper cartoons (Av. mean $=3.75)$. They however agreed that newspaper cartons and Epa have humorous appearances that entertain people in the community (Av. mean $=3.45$ ), that entertaining songs during Epa festival expose wrongdoings in the community like newspaper cartoons (Av. mean $=3.25)$, that entertaining dance during Epa festival helps to understand the mood of the country at any time (Av. mean $=3.35)$ and that Epa masks illustrate images and give the impression of movement like animated images in newspaper cartoons Av. mean =3.4). The foregoing results and confirmed by the researcher's personal observation assert the artistic and communicative connections between Epa festival and newspaper cartoons. In the area of artistic connection, the mask and costume bearing masquerades, singing and dancing which are integral parts of the festival which provide homour entertaining songs and dance steps to members of the community and visitors alike. The appearance of Epa masquerade in the costume of a woman while its voice sound like that of a man is in itself humorous, just like the appearance of cartoons. Singing, drumming and dancing are theatrical performances 
Oriola \& Tiamiyu: Artistic and Communicative Connections between Newspaper Cartooning and Epa Festival in Ijagun Community, Ogun State, Nigeria

that provide entertainment. The communicative values of Epa festival is inherent in awareness creation about happenings in the society. The festival also serves as an avenue for discussion of social and political issues and exposure of social vices in the immediate community and the larger society, though through humorous songs and dance steps. Therefore, just like newspaper cartoons, Epa festival plays crucial communicative function.

\section{Conclusion}

Cartoons are artistic and communication artifacts of every society; it is worthy of note that newspaper cartoons are humorous drawings that serve as a device in stabilizing the social and political system in Nigeria as well as forming public opinion on social and political issues among readers. Editorial cartoons reflect socio-political realities in the Nigerian society, though in a comic or witty manner. Cartoons inform the electorate of their rights as well as expose to the readers the ills going on in the society. Thus, the findings of this study corroborate previous research findings about the artistic values of newspaper cartoons through the use of humour and satire which provide entertainment to the reading audience on the one hand. On the other hand, this study, like previous ones, has affirmed that newspaper cartoons carry messages of news value as well as expose wrongdoing in the society, thereby serving as a means of cultural communication.

The mask is the most significant part of any masquerade which is worn as part of the costume on the head. The Yoruba people of Southwest Nigeria regard the human head (ori) as the most important part of a person. Likewise, the head is the most prominent part of Yoruba sculpture. Masquerading is usually employed as one of the major means of disseminating and preserving African culture. Masquerades generally display the cultural history of the people in theatrical performances. Same is applicable to Epamasquerades of the 
Ijagun community, Ogun State in Southwest Nigeria. The Epa masquerades express artistic projection of a people's image reality as perceived and conceived through masking, theatrical performance, forms and visual contents. Their headdresses or masks aesthetically reflect varying themes and display colourful complements to traditional costumes, thereby performing artistic functions like newspaper cartoons. The theatrical performances of singing, drumming and dancing communicate about happenings, expose social vices in the community and serve to preserve norms and values. Thus, a communicative connection between Epa festival and newspaper cartoons is hereby established as the latter also communicate issues of public interest. This study hereby affirms the artistic and communicative connections between newspaper cartooning and Epa festival in Ijagun community of Ogun State, Southwest Nigeria which is still preserved, practiced and sustained till date. In view of its artistic and communicative relevance to the immediate community where it is practiced and the larger society, Epa festival should be sustained for the purposes of creation of awareness within the community, entertainment, security through exposure of social vices and cultural transmission just as cartooning remains sustained as integral newspaper contents.

\section{References}

Abokede, O. O. (2018): Classification of Epa masquerades among Okun Yoruba of South Western Nigeria: A study of forms and aesthetics. American International Journal of Research in Humanities, Arts and Social Sciences. 23(1) 48-54.

Abokede, O. O. (2009). Egungun shrine paintings in the upper Ogun area of the Oyo State of Nigeria. Ela: Journal of African Studies. $25-26,1-25$.

Agberia, J. (2003). The role of cartoon in the social and cultural development of Nigeria.Nigerian Journal of Art, 2, 32-42. 
Oriola \& Tiamiyu: Artistic and Communicative Connections between Newspaper Cartooning and Epa Festival in Ijagun Community, Ogun State, Nigeria

Ayinmode, S. A. (2005). Epa masquerade costume in Okunland: An analysis of significance and forms. Unpublished B. Tech. Thesis, Department of Fine and Applied Arts, Ladoke Akintola University of Technology, Ogbomoso.

Ayinmode, S. A, \& Abokede, O.O. (2016).Re-Thinking the origin of Epa festival among Iyah Gbede, Okun Yoruba. International Journal of African Culture and Ideas, 16(1 \& 2), 91-112.

Booker, K. M. (2014).Comics through time: A history of icons, idols and ideas (Vol. 4). ABC-CLIO Publishers.

Birmingham Museum of Art (2010). Birmingham Museum of Art: Guide to the collection. Birmingham Museum of Art.

Carroll, K. (1967). Yoruba religious carving: Pagan and Christian sculpture in Nigeria and Dahomey. Geoffrey Chapma.

Caswell, L. S. (2002). Drawing Swords: War in American Editorial Cartoons. American Journalism, 21(2), 13-45.

Heyden, M.V. (1977). The Epa mask and ceremony. African Arts, 10(2), 17-28.

Johnston, J., \& Graham, C. (2012). The new, old journalism: Narrative writing in contemporary newspapers. Journalism Studies, 13(4), 517-533.

Maslin, M. (2016). The Peter Arno Cartoons That Help Rescue The New Yorker. The New Yorker,May 5. Retrieved from https://www.newyorker.com/books/page-turner/the-peter-arnocartoons-that-helped-rescue-the-new-yorker

McQuail, D. (2010). McQuail's mass communication theory $\left(6^{\text {th }}\right.$ edition). London: Sage Publications Limited.

Nasiru, A. \& Buike, O. (2017).Cartoon as a device for political critique in Nigerian Newspapers. The Beam Journal of Arts \& Science, 11(1), 1-9.

Ojo, J.R. O. (1978). The symbolism and significance of Epa-type masquerade headpieces. Man. New Series. 13(3), 455-470. 
Olaniyan, T. (2002).Cartooning Nigerian Anti-colonial Nationalism. In P. Landau, \& S. Griffin (Eds.), Images and empires: Visuality in colonial and postcolonial Africa ( $p$ p 89-115). Oxford University Press.

Oriola, O. (2012). An analysis of the agenda setting direction of The Guardian newspaper's editorial cartoons. African Journalism and Communication Review, 1(4), 57-70.

Oriola, M. O., \& Quadri, W. O. (2019). An analysis of patterns of framing The Punch newspaper's editorial cartoons in Nigeria, Journal of Studies in Humanities (JOSIH), 10, 134-153.

Shelton, A. (1998). A Yoruba Epa mask by Fasiku Alaye. Journal of Museum Ethnography.10,121-124.

Tejusoso, W. (2005). Basics of photojournalism. Jedichah Publishers. Thompson, R.F. (1974).African art in motion. University of California Press.

Mufutau Oluwakemi (PhD) is a lecturer in Department of Creative Arts, Tai Solarin University of Education, Ijagun, Ogun State, Nigeria.

Oludare Joseph Yiamiyu is a lecturer in Department of Creative Arts, Tai Solarin University of Education, Ijagun, Ogun State, Nigeria. 